\title{
River ice and water temperature prediction on the Danube
}

\author{
Zoltán Árpád LIPTAY¹, SZABolcs CZIGÁNY² and ERvin PIRKHOFFER ${ }^{3}$
}

\begin{abstract}
This paper presents a modification of the theory of weighted mean temperatures for rivers. RodHE, B. (1952) assumed the dominance of sensible heat transfer on ice formation. We aimed to improve the method for the evaluation of ice and water temperature based on a relatively low number of inputs. We further developed the model by introducing the effect of pre-existing ice, hence increasing the accuracy of the model on the timing of ice disappearance. Prediction accuracy of \pm 1 day was reached for the timing of the appearance of ice. Additional outputs have also been added to the model, including the termination of ice and the prediction of water temperature. The temperature calculation had a coefficient of determination of 95 percent, and a root mean square error of $1.33^{\circ} \mathrm{C}$ during the calibration period without the use of observed water temperatures. The validation was carried out in a forecasting situation, and the results were compared to the energy balance.
\end{abstract}

Keywords: hydrology; ice dynamics; forecast; water temperature; Danube

Received February 2020, accepted August 2021

\section{Introduction}

River ice development was directly observed on the Danube in January 2017, and the subsequent icy flood was extensively studied on the Tisza in February of the same year. These events highlighted that rivers can still present unexpected challenges in river ice management. A comprehensive report on these events was published by the International Commission for the Protection of the Danube River (Mladenović, B.M. et al. 2018). These events are serious threats and may profoundly impact local infrastructure and human life; hence, safe management is not only a priority but also a complex engineering task. Prediction and mitigation of events of this type are priorities and among the main tasks of fluvial hydrology.
The importance of river ice prediction on the Danube was first mentioned by LÁsZLófFY, W. (1934) for the optimal utilisation of the autumn navigation season. This is still one of the key reasons for river ice prediction because floating ice discs and sheets often reach a thickness of $60 \mathrm{~cm}$ and a diameter of 5 metres (Keve, G. 2012). Floating ice of this size may cause severe damage to ships and ferries, not just risking cargo but also threatening the lives of crew members and passengers. Navigation signs may also be damaged or destroyed by ice. Safe navigation of ice-breakers, however, is important, and their deployment has to be planned early enough for cost and time-efficient ice removal. Industrial utilisation such as hydroelectric power generation or cooling-water

\footnotetext{
${ }^{1}$ Hungarian Hydrological Forecasting Service. General Directorate of Water Management. H-1012 Budapest, Márvány u. 1/D. Hungary. E-mail: liptay.zoltan@ovf.hu, ORCiD: 0000-0001-8984-9366

${ }^{2}$ Institute of Geography and Earth Sciences, University of Pécs, H-7624 Pécs, Ifjúság útja 6. Hungary.

E-mail: sczigany@gamma.ttk.pte.hu, ORCiD: 0000-0002-9158-3162

${ }^{3}$ Institute of Geography and Earth Sciences, University of Pécs, H-7624 Pécs, Ifjúság útja 6. Hungary.

E-mail: pirkhoff@gamma.ttk.pte.hu
} 
of fossil and nuclear power plants is another key reason for river ice prediction. River ice forecast is closely connected to water temperature forecast due to the environmental regulations of cooling-water outlets. Riverrelated recreation and entertainment services can also rely on water temperature forecasts.

The research site was the Hungarian Danube reach with three selected gauging stations, namely at the settlements of Nagybajcs, Budapest and Paks (Figure 1). The study sites are characterised by a semi-humid temperate climate with oceanic (mostly in summer months), continental (mostly in winter months) and Mediterranean influences (Antal, E. 1997; Ács, F. and BAuer, H. 2013). River ice typically occurs between December and early March. The average temperature of the coldest month (January) is around $0{ }^{\circ} \mathrm{C}$. The number of frost days (daily minimum temperature $<0{ }^{\circ} \mathrm{C}$ ) and the number of winter days (daily maximum temperature $<0{ }^{\circ} \mathrm{C}$ ) reflects the local ice generation potential of winter seasons. Several studies on the longterm evaluation of the number of frost days are available (ANTAL, E. 1997; SzAlaI, S. and Szentimrey, T. 2005; Bihari, Z. 2018) that indicate a slight decrement of 0.14 days/year. The number of frost and winter days shows a wide variation across the country with an average of 90 to 100 frost days and 20 to 30 winter days along the Danube (BIHARI, Z. 2018).

Most of the water temperature models are either deterministic or statistical (BENYAHYA, L. et al. 2007). Deterministic models are mathematical representations of the physical processes, generally based on the energy balance approach. They require a great number of input data, but they are efficient tools for analysing the components of heat flux. Statistical models are classified into either parametric (regression and stochastic models) and nonparametric models (machine learning, artificial neural networks).

Westhoff, M. et al. (2007) published results of a detailed energy balance and temperature transport model on sub-catchments of the Maisbich catchment (Luxemburg). A small stream of approximately $600 \mathrm{~m}$ length with an average discharge of $1.21 \mathrm{l} / \mathrm{s}$ during the

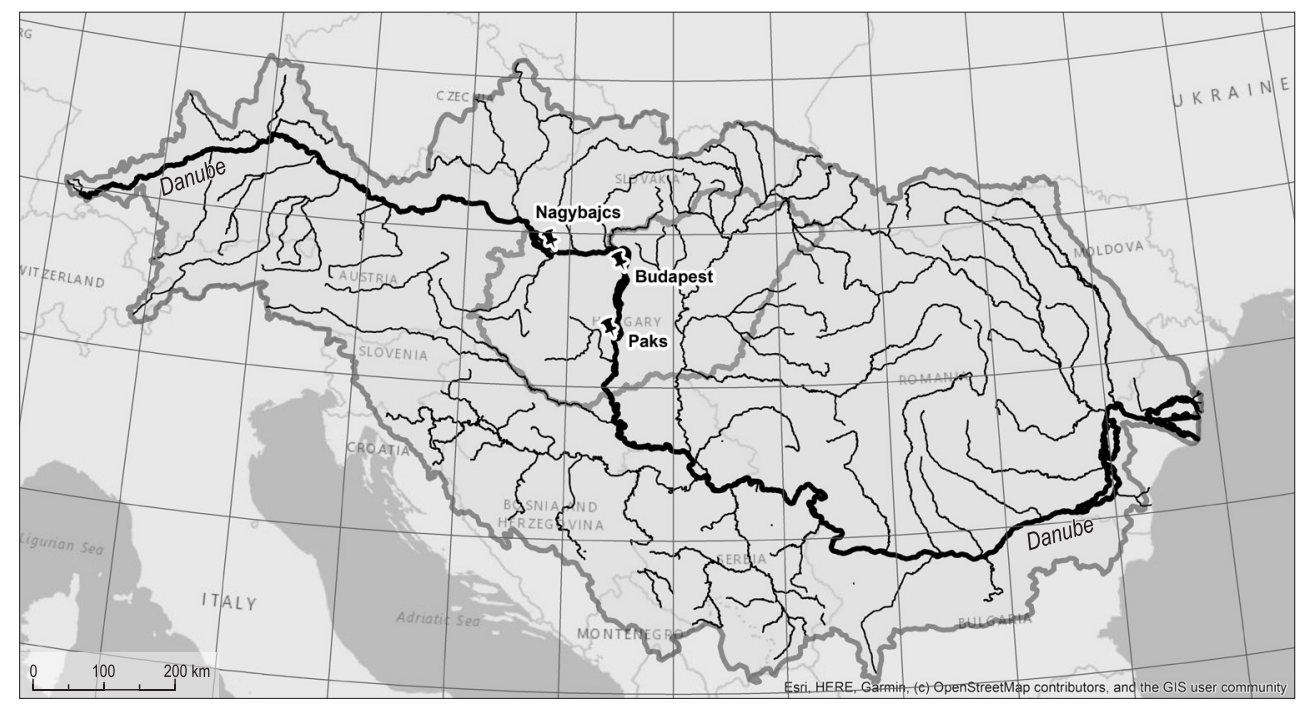

Fig. 1. Locations of the three selected stations in the Danube catchment 
observations was analysed. High-resolution temperature measurements were compared to the simulated results in order to identify the quantity and location of groundwater sources. The Root Mean Square Error (RMSE) of the model was only $1.01{ }^{\circ} \mathrm{C}$.

The results of statistical water temperature modelling were published by AhmadiNedushan, B. et al. (2007) on the Canadian Moisie River (annual mean discharge of $466 \mathrm{~m}^{3} / \mathrm{s}$ ). A sinusoidal annual component was estimated with the annual RMSE from $1.66^{\circ} \mathrm{C}$ to $2.21{ }^{\circ} \mathrm{C}$ for the calibration period, and residual short-term variations were implemented by additional models of 4 to 9 parameters. The presented RMSE ranged from $0.502{ }^{\circ} \mathrm{C}$ ( 9 variables) to $0.511{ }^{\circ} \mathrm{C}$ (4 variables) during calibration and from $0.521{ }^{\circ} \mathrm{C}$ (5 variables) to $0.533^{\circ} \mathrm{C}$ (6 variables) on validation.

A large-scale study was presented by vaN VLIET, M.T.H. et al. (2012) on the modelling of streamflow and water temperature on catchments of several hundreds of thousands of $\mathrm{km}^{2}$, including the Danube. The authors used a grid-based hydrological routing model coupled with a one-dimensional stream temperature model with daily time-step over a period of more than 20 years. Observations from 13 stations were compared to simulated water temperatures on the Danube, and the average RMSE of $2.5^{\circ} \mathrm{C}$ was achieved.

Certain components of the deterministic models are often derived from empirical relations, but there are also models that are physically-based only on sensible heat transfer but either completely neglect other terms or use conceptual and experimental additions to imitate the behaviour of the full energy balance. Toffolon, M. and Piccolroaz, S. (2015) published a hybrid model called air2stream, defining water temperature as a function of air temperature, discharge and a sinusoidal function for fictitious lateral inflows and heat fluxes. They selected three rivers in Switzerland with different hydrological conditions: the Mentue for a natural lowland type, the Rhtne at Sion for a regulated type, and the Dischmabach for a snowmeltfed type. The largest among the three is the
Rhtne with an annual average discharge barely above $100 \mathrm{~m}^{3} / \mathrm{s}$ at the city of Sion. However, besides its large number of input parameter requirements, high uncertainty of the heat fluxes was associated with the model. The RMSE values ranged from $0.58^{\circ} \mathrm{C}$ (8 input parameters) to $0.91{ }^{\circ} \mathrm{C}$ (3 parameters) on calibration, and from $0.62{ }^{\circ} \mathrm{C}(8$ parameters) to $1.05{ }^{\circ} \mathrm{C}$ (both 5 and 3 parameters) on validation. The model performance on the Rhtne was the least efficient, Nash-Sutcliff model efficiency coefficient (NSE, NASH, J.E. and Sutcliffe, I.V. 1970) were 0.89 for 8 and 7 parameters and 0.79 for 5,4 and 3 parameters.

An ensemble approach of water temperature forecast was published by OuelletProulx, S. et al. (2017). They modelled two Canadian catchments, the regulated Nechako (discharge regulated between $170-283 \mathrm{~m}^{3} / \mathrm{s}$ ) and natural Southwest Miramichi Rivers (mean discharge is $120 \mathrm{~m}^{3} / \mathrm{s}$ at the selected station). Their method was based on a semidistributed rainfall-runoff model called CEQUEAU and the estimation of energy balance terms at each grid cells. The RMSE values of the operational forecast system ranged from $0.81{ }^{\circ} \mathrm{C}$ on day 1 to $1.48{ }^{\circ} \mathrm{C}$ on day 3 based on an autoregressive model. The parameters of the thermal model were calibrated to get the best model performance over the summer period since the main target of their water temperature forecast was to minimise the exposure of aquatic organisms to high water temperature. RMSE values of $0.78^{\circ} \mathrm{C}$ on Nechako and $1.23^{\circ} \mathrm{C}$ on Miramichi were achieved during calibration on summer period, while $0.95{ }^{\circ} \mathrm{C}$ and $1.46{ }^{\circ} \mathrm{C}$ during validation. The year-round comparison resulted in $1.38{ }^{\circ} \mathrm{C}$ on Nechako and $1.37{ }^{\circ} \mathrm{C}$ on Miramichi for calibration and $1.54{ }^{\circ} \mathrm{C}$ and $1.51^{\circ} \mathrm{C}$ for validation.

Comparisons of six statistical models were carried out by $\mathrm{Z}_{\mathrm{HU}}$, S. et al. (2018) on the Missouri River $\left(Q_{\text {mean }} \approx 4,500 \mathrm{~m}^{3} / \mathrm{s}\right)$ at three stations: three regression-based parametric models with linear, non-linear and stochastic expressions, and three machine learning procedures (artificial neural networks, Gaussian process regression, Bootstrap ag- 
gregated decision trees). Poor performance of linear and non-linear regression was found, RMSE values ranged from $2.99{ }^{\circ} \mathrm{C}$ to $3.94^{\circ} \mathrm{C}$. The stochastic model performed better, RMSE values ranged from $1.72{ }^{\circ} \mathrm{C}$ to $2.14{ }^{\circ} \mathrm{C}$. Machine learning procedures all performed better, their RMSE ranged from $1.4950{ }^{\circ} \mathrm{C}$ to $1.9784{ }^{\circ} \mathrm{C}$. An earlier study on the Missouri is available from ZHANG, Z. and JoHnson, B.E. (2017), where they applied the temperature transport of HEC-RAS (Hydrologic Engineering Center - River Analysis System) but observed data were heavily limited. RMSE values of the HEC-RAS simulation are not published, but the RMSE values of linear regression at boundary conditions are published from $1.744{ }^{\circ} \mathrm{C}$ to $3.532^{\circ} \mathrm{C}$.

TAvares, A. et al. (2018) applied the model proposed by Toffolon, M. and Piccolroaz, S. (2015) on the river Cebollati, Uruguay $\left(Q_{\text {mean }} \approx 1,377 \mathrm{~m}^{3} / \mathrm{s}\right.$ at Lagoon Mirim) using water temperature derived from remote sensing (Landsat and MODIS) data. The RMSE of $1.296 \mathrm{~K}$ during calibration and 1.245 $\mathrm{K}$ were achieved.

Piotrowski, A.P. and Napiorkowski, J.J. (2018) aimed to find an effective calibration method for air2stream model. They compared twelve different calibration algorithms on six different streams of lowland, hilly and mountainous types with catchment size under $1,000 \mathrm{~km}^{2}\left(Q_{\text {mean }}<10 \mathrm{~m}^{3} / \mathrm{s}\right.$ in each case). A comparison was also done with classical data-driven models, namely the multiple linear regression, the MoHseni, O. et al. (1998) four-parameter model and its modified version by VAN VLIET, M.T.H. et al. (2011) with five parameters. The air2stream model produced an RMSE of $1.123{ }^{\circ} \mathrm{C}$ for calibration and 0.909 on validation for the largest river but also indicated a strong dependency on the optimisation method.

ZHU, S. et al. (2019) published a comparison of three machine learning methods (feedforward neural network, Gaussian process regression and decision tree) and the 8,5 and 3 parameter version of air 2 stream model on seven rivers. One of the rivers studied was the Drava with two selected gauging sta- tions at Botovo and Donji Miholjac $\left(Q_{\text {mean }} \approx\right.$ $500 \mathrm{~m}^{3} / \mathrm{s}$ ). An almost identical calibration RMSE was obtained for the two stations: $0.876,1.002,1.046{ }^{\circ} \mathrm{C}$ at Botovo and 0.876 , $0.959,0.955{ }^{\circ} \mathrm{C}$ at Donji Miholjac with 8,5 and 3 parameters. Validation RMSE values showed a greater difference: 0.891, 1.000, $1.006{ }^{\circ} \mathrm{C}$ at Botovo and $1.247,1.310,1.370{ }^{\circ} \mathrm{C}$ at Donji Miholjac. Their results showed that air2stream models generally outperform machine learning methods.

Numerous river ice prediction techniques and models have been developed and analysed in recent years. These approaches include statistical models such as the cumulative negative air temperature degreedays published by GRAF, R. and ToмсzYK, A.M. (2018), analytical formulations such as RICE (LAL, W.A.M. and SHEN, H.T. 1991) and RIVICE (LindensCHMidT, K-E. 2017) coupled with one-dimensional river hydraulics, and the two-dimensional DynaRICE (KolersKI, T. 2018). These models are capable of simulating small-scale dynamic river ice processes, but they require geometrical (digital terrain model for 2D, cross-sections for 1D) and hydrological (water levels and discharges for initial and boundary conditions) data for hydraulic simulations and data due to the deterministic approach on heat flux. Comparative testing of such models was also carried out by CARson, R. et al. (2011).

The above overview highlights that there are several methods tested and published for water temperature simulation, but their performance is highly dependent on the number of variables. Furthermore, the large number of variables makes the calibration procedure unavoidable. Findings also show a decreasing performance with increasing annual flow. In this paper, we aim to introduce a conceptual method with lumped parameters and minor data requirements, which at the same time provides satisfactory results on the Danube river. Such a model is highly flexible, easy to apply on rivers of similar characteristics and quickly provides results for decision-makers, stakeholders and operational application managers. 


\section{Materials and methods}

We chose the theory of weighted mean temperatures (RoDHe, B. 1952, 1955) as a basis. The theory, published by the Swedish meteorologist Bertil RodHe in 1952 and later in 1955, was an answer to the uncertain approach of temperature sum based methods (Östman, C.J. 1950; Nusser, F. 1950; Palosuo, E. 1951) of that era. This approach was specifically developed for marine application, but the U.S. Army Cold Regions Research and Engineering Laboratory experimented with river application (BILELlo, M.E. 1963) and also recommended further testing.

RHode assumed that all terms of the full energy balance are neglected but the direct energy transfer between water and air. The governing equation (1) is based on heat transfer which is induced on the boundary of water and air of different temperatures. Following RodHe's derivation from the Newtonian law of heat transfer and the equation of temperature change of water due to this transfer, we get to the continuous form of the basic equation:

$$
\frac{d \tau}{d t}=k(T-\tau),
$$

where $T$ is the air temperature $\left({ }^{\circ} \mathrm{C}\right), \tau$ is the water temperature $\left({ }^{\circ} \mathrm{C}\right), t$ is the time $(\mathrm{s})$, and $k$ is the time inverse coefficient $(1 / \mathrm{s})$ or a constant with an inverse dimension of time (Rodhe, B. 1952, 1955; Bilello, M.E. 1963). The equation simply describes the change of water temperature as a proportion of the difference of water and air temperatures, where the rate is symbolised with a time inverse coefficient. From the derivation, it is clear that the physical content of the $k$ constant is the summation of all the material parameters of heat exchange:

$$
k=\frac{\alpha}{c \gamma h \rho}
$$

where $k$ is the time inverse coefficient $(1 / \mathrm{s})$, $\alpha$ is the heat transfer coefficient $\left.\left(\mathrm{W} / \mathrm{m}^{2} /{ }^{\circ} \mathrm{C}\right)\right]$, $c$ is the specific heat of water $\left(\mathrm{J} / \mathrm{kg} /{ }^{\circ} \mathrm{C}\right), h$ is the depth of heat exchanging water layer $(\mathrm{m})$, $\gamma$ is the ratio of the change in surface tem- perature and the change in the mean temperature of the heat exchanging subsurface layer $(0<\gamma<1)$, and $\rho$ is the density of water $\left(\mathrm{kg} / \mathrm{m}^{3}\right)$. After the solution and discretisation of the basic differential equation (1), the final form is equation 3 .

$$
\tau_{n}=\tau_{n-1}+\left(1-e^{-k \Delta t}\right)\left(T_{n}-\tau_{n-1}\right),
$$

where $T_{n}$ is the average air temperature at a time step $t_{n-1}-t_{n}\left({ }^{\circ} \mathrm{C}\right), \tau_{n}$ is the temperature of the water surface at $t_{n}\left({ }^{\circ} \mathrm{C}\right), \tau_{n-1}$ is the temperature of the water surface at $t_{n-1}\left({ }^{\circ} \mathrm{C}\right), \Delta t$ is time step (s) and $k$ is a constant with an inverse dimension of time $(1 / \mathrm{s})$.

Since the method was developed for the prediction of the onset of ice formation, the free variable $k$ should be selected in such a way that the series of $\tau$ reached a freezing point when the first patch of ice was observed. Promising results were obtained by applying the method on the Danube river in Hungary on the ice events from 2008 to 2017 (LiptAy, Z.Á. 2018).

During the process of adaptation, we focused on empirical approaches for maximising the efficiency of the method while conserving its modest need for data and computational capacity. The first step of adaptation was to introduce the ability to predict the disappearance of ice. By dividing the lag parameter with different values at sub-zero temperatures then at above freezing the method becomes capable to simulate this phenomenon. We simplified this to a ratio of the original lag value, therefore only one new variable was introduced.

$$
k=\left\{\begin{array}{lr}
k & \text { if } \tau_{n-1}>0 \\
k \cdot r & \text { if } \tau_{n-1}<0 \text { and }\left(T_{n}-\tau_{n-1}\right)<0 \\
\frac{k}{r} & \text { if } \tau_{n-1}<0 \text { and }\left(T_{n}-\tau_{n-1}\right)>0
\end{array}\right\}
$$

where $r$ is the correction of $k$ when the $\tau$ function is negative $[-](1<r)$.

The second adaptation step was to estimate the evolution of water temperature. We calibrated the parameters towards water temperature and obtained a close correlation between the $\tau$ series and observed water temperatures. 
A difference in the temperature gradients was found at $4{ }^{\circ} \mathrm{C}$, comparing the observed and calculated water temperatures. The $\tau$ series calibrated for water temperature calculation continues to react intensively for further cooling; however, observed water temperatures show only moderate changes. Mohseni, O. and StEFAn, H.G. (1999) analysed the relationship between water temperature and air temperature based on physical interpretation and defined four ranges:

1) air temperature is under $-10{ }^{\circ} \mathrm{C}$, and the equilibrium water temperature is around $0{ }^{\circ} \mathrm{C}$;

2) air temperature is between -10 and $0{ }^{\circ} \mathrm{C}$ while stream temperature is above $0{ }^{\circ} \mathrm{C}$ and increased significantly with air temperature, but the slope of their relationship is defined by groundwater;

3) air temperature is between 0 and $20^{\circ} \mathrm{C}$, and water temperature tends to change linearly with air temperature;

4) high air temperatures, and water temperature rises slowly with air temperature.

These ranges resemble an S-shaped relation of water temperatures and air temperatures. Figure 2 shows the relation of weekly water temperature and air temperature measures at the Budapest gauging station from 2008 to 2017. The S-shaped relation is clearly visible, and while both linear and polynomial regressions have high and nearly equal $r^{2}$ over the entire set of data, linear re- gression shows poor performance in Ranges 2 and 4 .

As a result, we divided the lag value into two parts at the arbitrarily selected $4{ }^{\circ} \mathrm{C}$ threshold to follow this relation:

$$
k=\left\{\begin{array}{lr}
k & \text { if } \tau_{n-1}>4 \\
k_{\text {below } 4^{\circ} \mathrm{C}} & \text { if } \tau_{n-1}<4, \text { and } \tau_{n-1}>0 \\
k \cdot r & \text { if } \tau_{n-1}<0 \text { and }\left(T_{n}-\tau_{n-1}\right)<0 \\
\frac{k}{r} & \text { if } \tau_{n-1}<0 \text { and }\left(T_{n}-\tau_{n-1}\right)>0
\end{array}\right\}
$$

An example is presented in Figure 3. The first parameterisation (Rodhe $1 / \mathrm{k}=10$ days) adequately reproduces the observed water temperatures but gives an erroneous ice prediction. The second parameterisation (Rodhe 1/k $=17.7$ days) scheme gives an accurate ice prediction but overestimates water temperatures. A combination of the two (RodHe combined) gives a method applicable to both situations.

As a third adaptation step, we assumed that water temperature calculated at $t_{n}$ is not only the function of water temperature at $t_{n-1}$ and the mean temperature of the station but also the mean temperature of the upstream station at $t_{n-m^{\prime}}$ where $m$ is the distance of the stations in time.

$$
T_{n}=z \times T_{n, \text { local }}+(1-z) T_{n-m, \text { upstream }},
$$

where $T_{n}$ is the resulting daily mean air temperature at time step $t_{n-1}-t n\left({ }^{\circ} \mathrm{C}\right), T_{n, \text { local }}$ is the

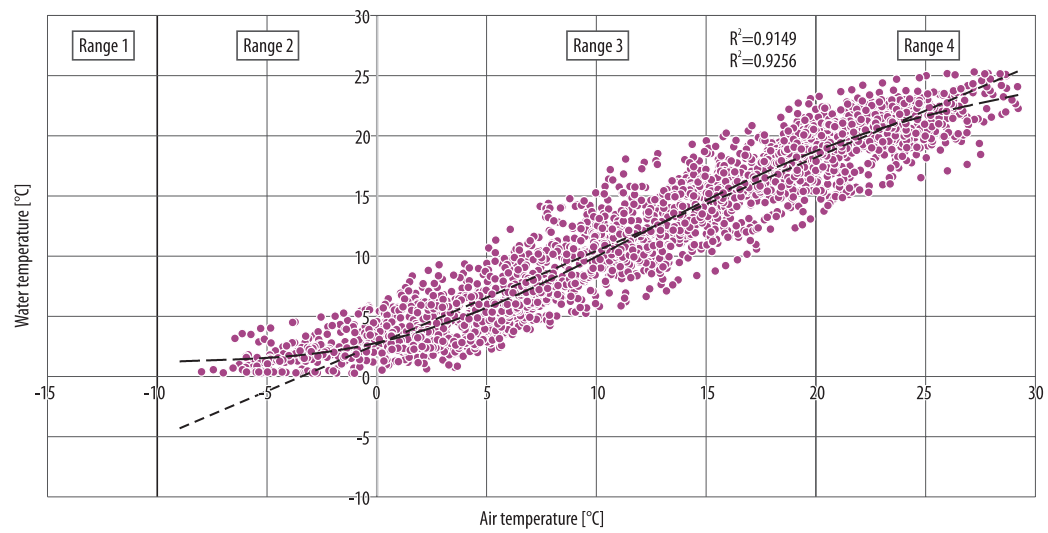

Fig. 2. Relation of weekly water temperature and air temperature on the Danube at Budapest 


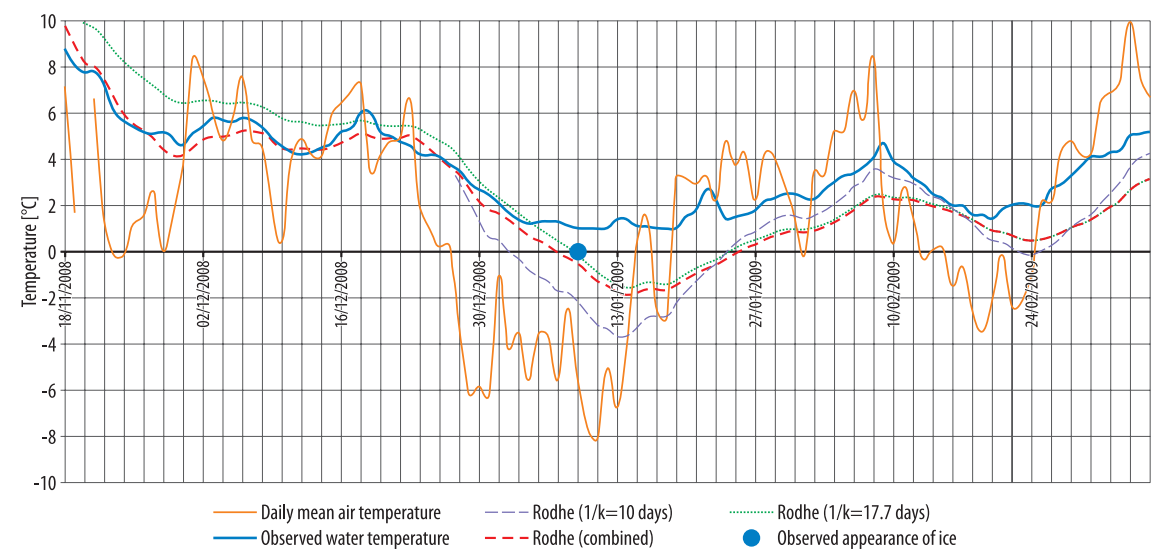

Fig. 3. The combination of water temperature and ice forecast

local daily mean temperature $\left({ }^{\circ} \mathrm{C}\right), T_{n-m, u p s t r e a m}$ is the daily mean air temperature at the upstream station $\left({ }^{\circ} \mathrm{C}\right), z$ is a factor dependent on flow regime [-].

$$
z=1-\left(M T_{n} \times s\right)
$$

where $z$ is a factor dependent on flow regime [-], $M T_{n}$ is the daily value of flow regime (\%), $s$ is a calibration parameter [-]. The value of $z$ should be chosen to simulate the local impact during low flow and the increasing weight of upstream impact with the rising water level. The daily flow values were derived from the observed water levels in the hindcast period and from predicted water levels in the forecast period.

Upscaling and positioning the aforementioned methods to a new perspective of complex hydrological networks, the influence of tributaries is a key factor on ice formation and dynamics. By analysing the ice event of January 2017 on the Danube river, the influence of the Váh river is evident on the ice formation of the main stream. Satellite images, acquired by for instance, the Sentinel-2A satellite at a spatial resolution of $10 \times 10$ metres, may also provide important information on riverine ice dynamics. For the current study, Sentinel-acquired satellite imagery taken on 8 January was used (Figure 4).
The light coloured pixels of floating ice sheets were easily recognisable without any further image analysis; however, an averaging of bands was done to obtain a grayscale version. There were no drifting ice formations upstream of the junction, whereas drifting ice was observable on the Váh river. The ice sheets floated along the left bank following their arrival into the confluence with the Danube. Subsequently, using the available ice forming potential of the Danube, the ice cover broadened and covered the entire water surface on the right side of the image near the town of Almásfüzitő. It is challenging to explain this phenomenon with the theory of weighted mean temperatures; hence, we assumed that the selected set of parameters explain the general ice dynamics.

\section{Results and discussion}

Calculations with the original and the modified Rhode method were carried out for the period of 1 July 2008 to 31 August 2017. The initial conditions were the monthly average air temperatures of June 2008 in each case. Four ice cover events (2008-2009, 2009-2010, 2011-2012 and 2016-2017) occurred in this period. The first event was used solely for 


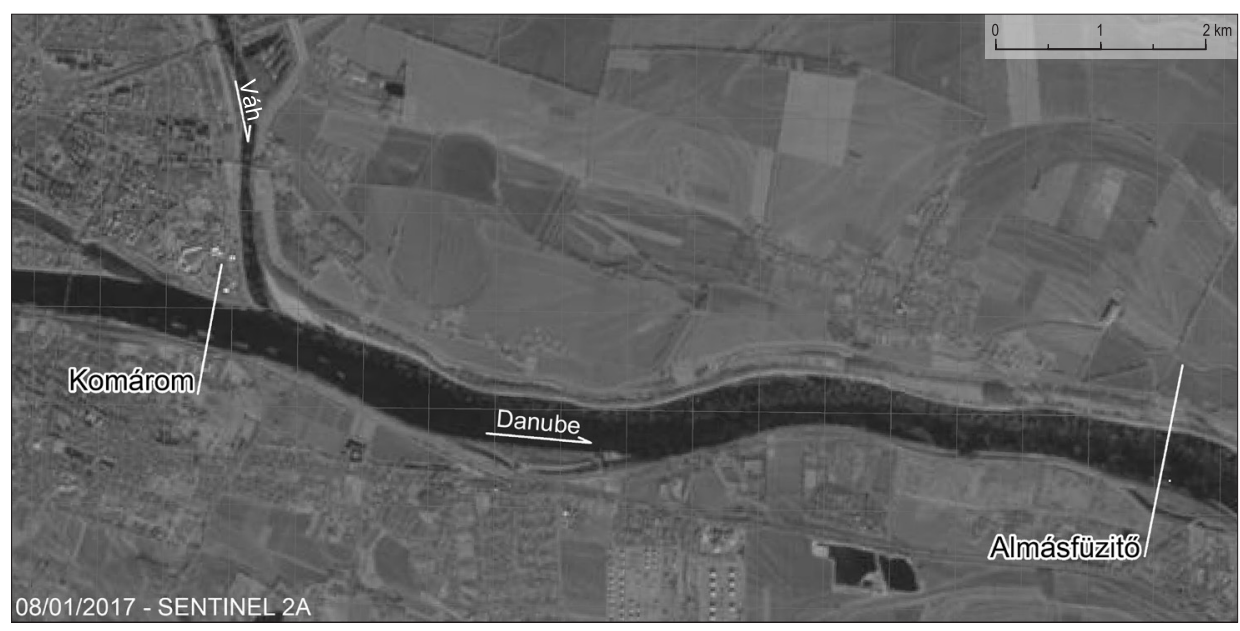

Fig. 4. Sentinel-2A image, 08.01.2017.

calibration purposes at each station, whereas the other three events were for validation. The values of lag and the later introduced parameters of equations (5) and (7) were calibrated using a trial-and-error approach with the target functions to minimise the RMSE and hit the day the ice run started and ended. Nagybajcs station is downstream of Gabčikovo reservoir (Slovakia); thus, the outflow from the reservoir heavily influences the water temperatures and ice formation resulting in only two observed ice events in 2011-2012 and 2016-2017. According to Mohseni and Stefan (1999) Range 1 and Range 2 of the water temperature and air temperature relation are influenced by the artificial upstream water temperature.

Table 1 includes the results of the prediction of ice appearance and disappearance with both the modified and original methods in brackets. A zero value means an exact match with observations; a negative value refers to ice predicted prior to the observed onset of icing; and a positive value means that ice was predicted later than the actual timing (all units are in days).

The last two rows of Table 1 indicate the efficiency of water temperature calculation of the modified method, namely the root mean square error and the determination coefficient. The ice appearance prediction efficiency of the original method in our case was between +2 and -2 days, and two out of the seven validation dates were precisely given. After the implementation of the modifications, this efficiency increased to \pm 1 day, and three out of the seven validation dates were precisely simulated by the model. The original method did not provide usable results regarding the disappearance of the ice, but after the modification, the validation succeeded, with only one icy period (2009-2010) being a major error. The RMSE and $r^{2}$ values of water temperature simulation of $1.46^{\circ} \mathrm{C}$ and 93.3 percent were achieved at the Nagybajcs gauging station during the calibration. This station is the most upstream station, meaning equation (6) is not applicable. The RMSE and $r^{2}$ values at Budapest were $1.19{ }^{\circ} \mathrm{C}$ and 96.3 percent, while $1.32{ }^{\circ} \mathrm{C}$ and 95.7 percent at Paks, respectively.

The most recent heavy icy event on the Danube was observed in January and February 2017 (Figure 5). After an abrupt drop in air temperature, a thick layer of ice cover was formed on the river covering more than 80 percent of the river surface at Budapest on 8 January 2017. The modified algorithm 
Table 1. Validation results on ice occurrence and disappearance prediction efficiency on the Danube and correlation of observed and calculated water temperatures

\begin{tabular}{|c|c|c|c|}
\hline \multirow[b]{2}{*}{ Ice observation period } & \multicolumn{3}{|c|}{ Ice prediction error, days } \\
\hline & $\begin{array}{l}\text { Nagybajcs, } \\
1,801.0 \mathrm{rkm}\end{array}$ & $\begin{array}{l}\text { Budapest, } \\
1,646.5 \mathrm{rkm}\end{array}$ & $\begin{array}{c}\text { Paks, } \\
1,531.3 \mathrm{rkm}\end{array}$ \\
\hline $\begin{array}{l}2008-2009 \\
2009-2010 \\
2011-2012 \\
2016-2017\end{array}$ & $\begin{array}{c}- \\
- \\
\text { calibration } \\
-1 ; 0(2 ; 0)\end{array}$ & $\begin{array}{c}\text { calibration } \\
0 ; 7(0 ; 15) \\
1 ; 1(-2 ; 11) \\
0 ; 0(-1 ; 19)\end{array}$ & $\begin{array}{c}\text { calibration } \\
-1 ; 9(-1 ; 15) \\
-1 ; 1(-2 ; 12) \\
0 ;-1(0 ; 18)\end{array}$ \\
\hline \multicolumn{4}{|c|}{ Correlation of observed and calculated water temperature } \\
\hline $\begin{array}{l}\text { RMSE, calib./valid., }{ }^{\circ} \mathrm{C} \\
\mathrm{r}^{2} \text {, calib./valid., } \%\end{array}$ & $\begin{array}{l}1.46 / 1.80 \\
93.3 / 92.8\end{array}$ & $\begin{array}{l}1,19 / 1.17 \\
96.2 / 97.5\end{array}$ & $\begin{array}{l}1,32 / 1.22 \\
95.7 / 97.3\end{array}$ \\
\hline
\end{tabular}

${ }^{*}$ Results with the original method of RodHe, B. (1952) are in brackets.

exactly hit the day that the ice run started and the day it finally stopped, and it also represented the dynamics, a clear advancement from the original method (Figure 6).

The calibration of the water temperature simulations was carried out for the entire study period, while the validation was only done for the period of 1 July 2017 to 30 June 2018. The RMSE and $r^{2}$ are presented in Table 1. Validation RMSE at Nagybajcs station was $1.80^{\circ} \mathrm{C}$, a slightly lower efficiency was obtained by the calibration. The RMSE of validation reached $1.17^{\circ} \mathrm{C}$ and $1.22{ }^{\circ} \mathrm{C}$ at Budapest and Paks, respectively. The reason for better performance during the validation is assumed to be the ice-free period chosen for validation when water temperature remained mainly in Ranges 3 and 4 .

Further analyses were also done by simulating operative forecast and providing ECMWF temperature predictions as input. We compared the results to the estimation of energy balance (EEB) at Paks station. The RMSE values for the calibration period between 2010 and 2017 based on observed and forecasted water temperature values are presented in Figure 7. The initial condition of the energy balance was the latest observed water temperature, while the results of the modified Rodhe method were corrected with

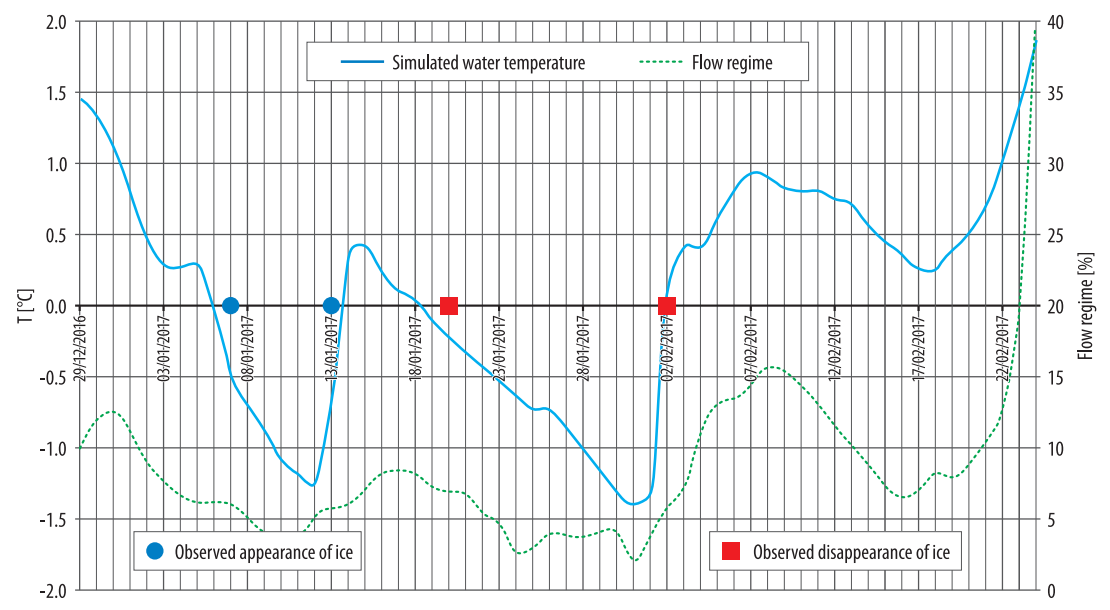

Fig. 5. Ice event in January 2017 at Budapest on the Danube compared to the results of the modified Rodhe method 


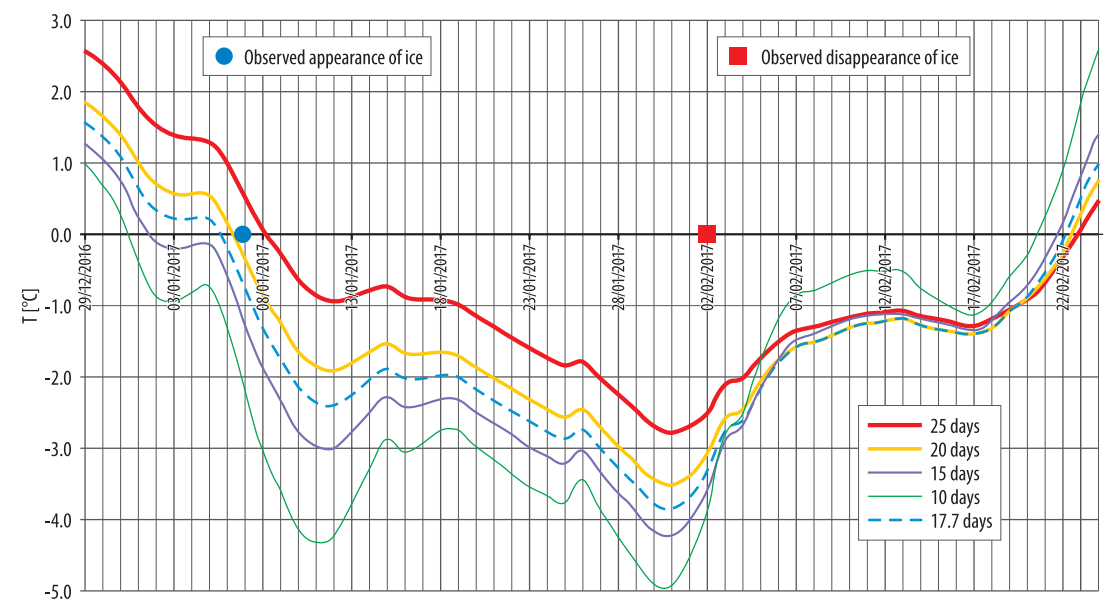

Fig. 6. Ice event in January 2017 at Budapest on the Danube compared to original Rodhe method with different lag time values

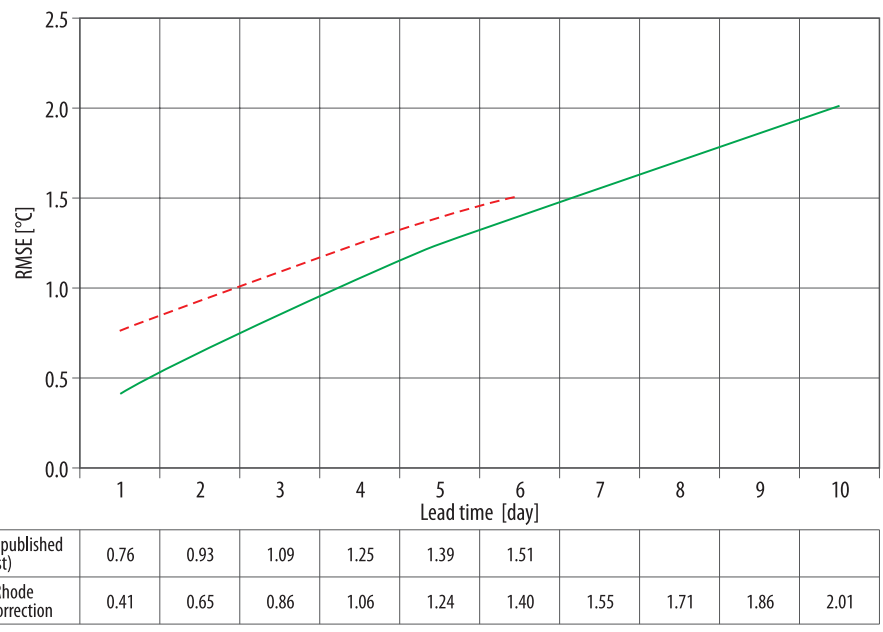

Fig. 7. RMSE values of water temperature forecast based on the estimation of energy balance (EEB) and the modified Rhode method from 2010 to 2017 on the Danube at Paks.

the error on the day of the forecast, and both of the calculations were driven by the daily mean air temperature derived from ECMWF meteorological forecast of the exact day. The correction technique was a simple deduction of error of the day of forecast.

The ECMWF based analysis was also done for the validation period. RMSE values are listed in Table 2 for all three stations, while
Figure 8 presents the comparison of the results at Paks with archived published six forecasts: - No. 1 presents the result with the modified Rodhe method without taking into account water temperature observations.

- No. 2 shows the result with the modified Rodhe method without hindcast but started from the observed value at the time of forecast. 
Table 2. RMSE $\left({ }^{\circ} \mathrm{C}\right)$ of water temperature forecast based on ECMWF temperature prediction in the validation period 01.07.2017-30.06.2018

\begin{tabular}{l|c|c|c|c|c|c|c|c|c|c}
\hline \multicolumn{1}{c}{ Lead time, day } \\
\hline \multicolumn{1}{c|}{ Station } & 1 & 2 & 3 & 4 & 5 & 6 & 7 & 8 & 9 & 10 \\
\hline Nagybajcs & 1.91 & 2.02 & 2.13 & 2.25 & 2.34 & 2.41 & 2.49 & 2.58 & 2.68 & 2.77 \\
Budapest & 1.20 & 1.22 & 1.31 & 1.41 & 1.50 & 1.59 & 1.68 & 1.76 & 1.85 & 1.92 \\
Paks & 1.25 & 1.32 & 1.38 & 1.46 & 1.53 & 1.61 & 1.68 & 1.75 & 1.84 & 1.92 \\
\hline
\end{tabular}

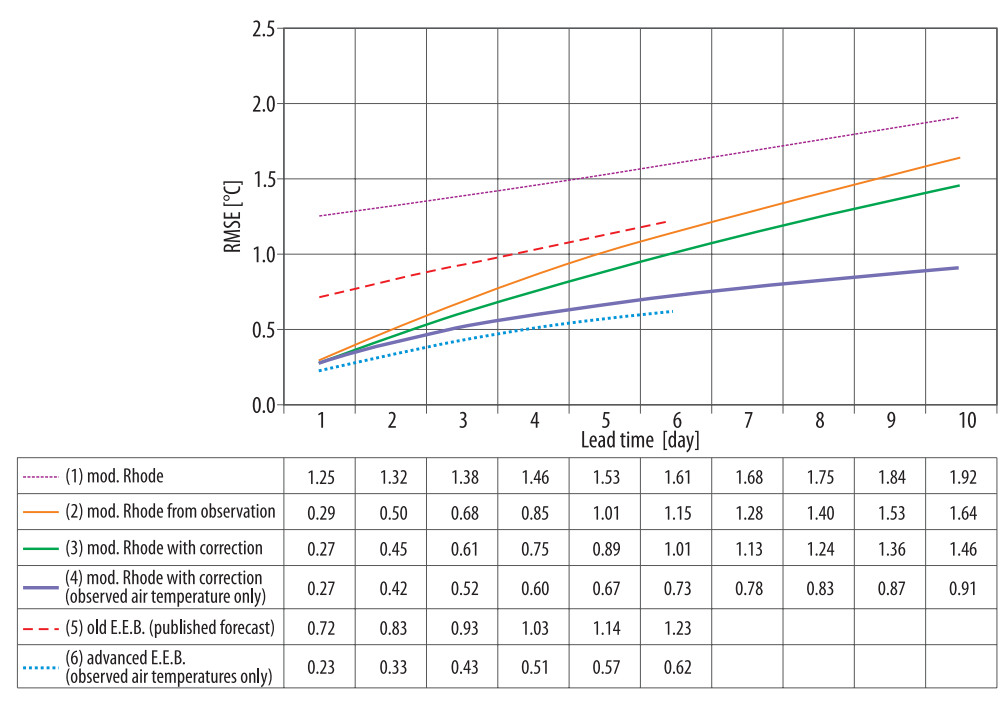

Fig. 8. RMSE values of water temperature forecast based on the estimation of energy balance (EEB) and the modified Rhode method with and without correction from 01/07/2017 to 30/06/2018 on the Danube at Paks.

- No. 3 is similar to no. 1 , but the predicted water temperatures are corrected with the error measured on the day of the forecast. This approach provides the best results regarding the RMSE of the water temperature forecast.

- No. 4 shows the results with the modified Rhode method after the correction with the error measured at the time of forecast, similarly to Series no. 3. The difference is that the mean air temperature values are not from ECMWF forecasts, but directly from the averaging of hourly observations. The difference between Series no. 3 and 4 indicates the uncertainty introduced by the meteorological forecast.

- No. 5 shows the published water temperature forecasts of this period calculated by the estimated energy balance based on ECMWF temperature forecasts.
- No. 6 presents the results of an ongoing update of the estimated energy balance based method. This update includes the recalibration of parameters on the period of 1 July 2015 to 30 June 2017 and validation from 1 July 2017 to 30 June 2018 and also includes the introduction of a new approach for the estimation of the albedo of water surface compared to the previously used constant value. The input for this calculation was purely observed data, and no ECMWF forecasts were included.

\section{Conclusions}

We found the weighted mean temperatures model of RodHe, B. (1952) applicable for the simulation of ice dynamics on the Danube 


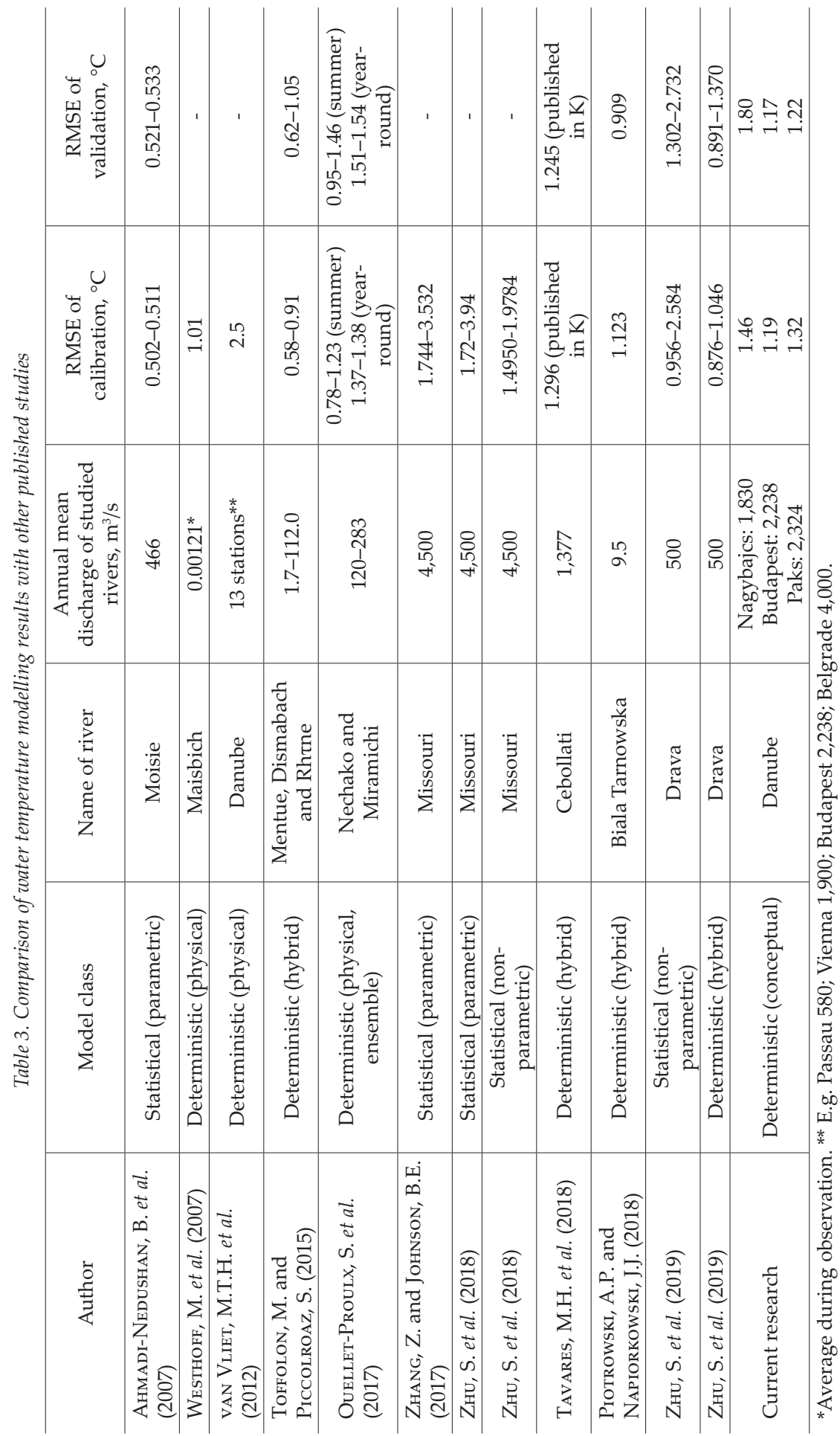


at the three selected stations. We further refined the model for increased accuracy on the temporal dynamics of ice cover. The original equation predicted ice cover for ice-free periods and predicted icy periods with an accuracy of \pm 2 days. (Liptay, Z. Á. 2018).

The empirically based modifications affected the results positively and strengthened the validity in the study area. A precision comparable to the estimated energy balance method was achieved based on the theory of weighted mean temperatures with a simple algorithm and fewer parameters.

Findings of five statistically and seven deterministically based former studies indicate that water temperature modelling is generally less efficient on larger rivers (BENYAHYA, L. et al. 2007; Westhoff, M. et al. 2007) (Table 3).

While the RMSEs ranged between $0.5^{\circ} \mathrm{C}$ and $1{ }^{\circ} \mathrm{C}$ for a river of $Q_{\text {mean }}<500 \mathrm{~m}^{3} / \mathrm{s}$ for both deterministic and statistic models, they increase to the range of $1-4{ }^{\circ} \mathrm{C}$ for larger rivers. The proposed model of the current study is in the middle of the list regarding the RMSEs if flow values are disregarded but shows superior performance for rivers with nearly equal or higher discharge and performs better than any other model used for the Danube. The number of free parameters for water temperature calculation is four in the present study, namely the two lag $(1 / k)$ values above $0{ }^{\circ} \mathrm{C}$ and the calibration variable (s) for flow regime, with another variable $(r)$ being introduced during ice formation. Toffolon and Piccolroaz (2015) presented a 3-parameter version of the air2stream model, also applied by ZHU, S. et al. (2019), but its performance is poor compared to the very well performing 8-parameter version. Nonetheless, the large number of parameters is the price for simplicity and comes with significant dependence on the calibration method (Ріотrowski, A.P. and NAPIORKowski, J.J. 2018).

\section{REFERENCES}

Ács, F. and Bauer, H. 2013. Biofizikai éghajlatosztályozási módszerek (Biophysical climate classification methods). Budapest, Eötvös Loránd Tudományegyetem.
Ahmadi-Nedushan, B., St-Hilaire, A., Ouarda, T.B.M.J., Bilodeau, L., Robichaud, É., Thiémonge, N. and Bове́́, B. 2007. Predicting river water temperatures using stochastic models: case study of the Moisie River. Hydrological Processes 21. 21-34. Doi: 10.1002/hyp.6353

AntAL, E. 1997. Éghajlat (Climate). In Magyarország a XX. században, II. kötet. Editor-in-chief: Kollega TARsoly, I. Szekszárd, Babits Kiadó, 27-38. (in Hungarian)

Benyahya, L., Caissie, D., St-Hilaire, A., Ouarda, T.B.M.J. and BoвÉE, B. 2007. A review of statistical water temperature models. Canadian Water Resources Journal 32. (3): 179-192.

Bihari, Z. (ed.) 2018. V. Éghajlat (V. Climate) In Magyarország Nemzeti Atlasza, II. kötet. Természeti környezet. Editor-in chief: Kocsis, K. Budapest, MTA CSFK, 58-69. (in Hungarian)

Bilello, M.E. 1963. Method of Predicting River and Lake Ice Formation. Hanover. U.S. Army Cold Regions Research and Engineering Laboratory.

Carson, R., Beltaos, S., Groenveld, J., Healy, D., She, Y., Malenchak, J., Morris, M., Saucet, J-P., Kolerski, T. and SHEN, H.T. 2011. Comparative testing of numerical models of river ice jams. Canadian Journal of Civil Engineering 38. 669-678. Doi:10.1139/L11-036.

Graf, R. and ToмczYк, A.M. 2018. The impact of cumulative negative air temperature degree-days on the appearance of ice cover on a river in relation to atmospheric circulation. Atmosphere 9. 204. Doi: 10.3390/atmos9060204

Keve, G. 2012. 2012. évi dunai jégészlelés tapasztalatai (Experiences of ice observation on the Danube in 2012). ADU-NEKI beszámoló jelentés a 2012. évi dunai jégészlelésről. Baja, Alsó-Duna-völgyi Vízügyi Igazgatóság. (in Hungarian)

KolERSKI, T. 2018. Mathematical modelling of ice dynamics as a decision support tool in river engineering. Water 10. 1241. Doi: 10/3390/w10091241

LAL, W.A.M. and SHEN, H.T. 1991. Mathematical model for river ice processes. Journal of Hydraulic Engineering 117. (7): 851-867.

LÁszLóFFY, W. 1934. Folyóink jégviszonyai különös tekintettel a magyar Dunára (The ice conditions of our rivers, especially the Hungarian Danube). Vizügyi Közlemények 16. (3): 369-435.

LiNDENSCHMIDT, K-E. 2017. RIVICE-A non-proprietary, open-source, one-dimensional river-ice model. Water 9. 314. Doi: $10.3390 / \mathrm{w} 9050314$

Liptay, Z.Á. 2018. Jégmegjelenés előrejelzése a súlyozott középhőmérsékletek elve alapján a Duna hazai szakaszára (Forecast of ice appearance based on the theory of weighted mean temperatures for the Hungarian Danube reach). Hidrológiai Közlöny 98. (1): 25-32.

Mladenović, B.M., Gombás, K., LišKa, I. and BaLatonyi, L. 2018. Report on the ice event 2017 in the Danube river basin. Vienna, ICPDR. 
Mohseni, O., Stefan, H.G. and Erickson, T.R. 1998. A nonlinear regression model for weekly stream temperatures. Water Resources Research 34. (10): 2685-2692.

Mohseni, O. and Stefan, H.G. 1999. Stream temperature/air temperature relationship: a physical interpretation. Journal of Hydrology 218. 128-141.

Nash, J.E. and Sutcliffe, I.V. 1970. River flow forecasting through conceptual models. Part I. Journal of Hydrology 10. 282-290.

Nusser, F. 1950. Gebiete gleicher Eisvorbereitungszeit an den deuschen Küsten. Deutsche Hydrographische Zeitschrift 3. (3-4): 220-227.

Ouellet-Proulx, S., St-Hilaire, A. and Boucher, M-A. 2017. Water temperature ensemble forecasts: Implementation using the CEQUEAU model on two contrasted river systems. Water 9. 457.1-21. Doi: 10.3390/w9070457

Östman, C.J. 1950. Om sambandet mellan köldsummor, isläggning och istjocklek. Meddelanden írån Sveriges meteorologiska och hydrologiska institute, Serie A. No. 1.

Palosuo, E. 1951. Ice in the Baltic and the meteorological factors. Journal du Conceil International pour l'Exploration de la Mer 17. (2): 124-132.

Piotrowski, A.P. and Napiorkowski, J.J. 2018. Performance of the air2stream model that relates air and stream water temperatures depends on the calibration method. Journal of Hydrology 561. 395-412. Available at https://doi.org/10.1016/j.jhydrol.2018.04.016

RoDHe, B. 1952. On the relation between air temperature and ice formation in the Baltic. Geografiska Annaler 34. 175-202.

RoDHe, B. 1955. A study of the correlation between the ice extent, the course of air temperature and the sea surface temperature in the Åland Archipelago. Geografiska Annaler 37. 141-163.

Szalai, S. and Szentimrey, T. 2005. Melegedett-e Magyarország éghajlata a XX. században? (Has Hungary's climate warmed in the $20^{\text {th }}$ century?). Statisztikai Szemle 83. (10-11): 978-989.

Tavares, M.H., da Cunha, A.H.F., Ruhoff, A. and de Motta Marques, D. 2018. Applying a water temperature model to river and calibrating it with downscaled remote sensing data. Geophysical Research Abstracts 20. Available at https://ui.adsabs.harvard. edu/abs/2018EGUGA..2015016T/abstract

Toffolon, M. and Piccolroaz, S. 2015. A hybrid model for river water temperature as a function of air temperature and discharge. Environmental Research Letters 10. 114011. Doi:10.1088/1748-9326/10/11/114011

van Vliet, M.T.H., Ludwig, F., Zwolsman, J.J.G., Weedon, G.P. and Kabat, P. 2011. Global river temperatures and sensitivity to atmospheric warming and changes in river flow. Water Resources Research 47. W02544. Available at https://doi. org/10.1029/2010WR009198 van Vliet, M.T.H., Yearsely, J.R., Franssen, W.H.P., Ludwig, F., Haddeland, I., Lettenmaier, D.P. and KавAт, P. 2012. Coupled daily streamflow and water temperature modelling in large river basins. Hydrology and Earth System Sciences 16. 4303-4321. Doi: 10.5194/hess-16-4303-2012

Westhoff, M., Hubert, S., Luxemburg, W., Stelling, G., van de Giesen, N., Selker, J., Pfister, L. and Uhlenbrook, S. 2007. A distributed stream temperature model using high resolution temperature observations. Hydrology and Earth System Sciences 11. 1469-1480. Doi: 10.5194/hessd-4-125-2007

Zhang, Z. and Johnson, B.E. 2017. Hydrologic Engineering Center - River Analysis System (HECRAS) water temperature models developed for the Missouri River Recovery Management Plan and Environmental Impact Statement. Technical report. Vicksburg, MS, U.S. Army Engineer Research and Development Center, Environmental Laboratory.

Zhu, S., Nyarko, E.K. and Hadzima-Nyarko, M. 2018. Modelling daily water temperature from air temperature for the Missouri River. PeerJ 6:e4894. Available at http://doi.org/10.7717/peerj.4894

Zhu, S., Nyarko, E.K. and Hadzima-Nyarko, M., Heddam, S. and Wu, S. 2019. Assessing the performance of a suite of machine learning models for daily river water temperature prediction. PeerJ 7:e7065. Available at http://doi.org/10.7717/ peerj.7065 